\title{
Risk factors associated with Dengue incidence in Bandung, Indonesia: a household based case-control study
}

DOI: dx.doi.org/10.22435/hsji.v11i1.3150

Hubullah Fuadzy, Mutiara Widawati, Endang P. Astuti, Heni Prasetyowati, Joni Hendri, Rohmansyah W. Nurindra, Dewi N. Hodijah.

Unit of Health Research and Development of Pangandaran District, West Java Province, Ministry of Health of Republic of Indonesia

Corresponding author: Hubullah Fuadzy

Email: hubullah_fy@yahoo.com

Received: Desember 9, 2019; Revised: Januari 20, 2020; Accepted: May 19, 2020.

\begin{abstract}
Abstrak
Latar belakang: Bandung memiliki daerah perkotaan dengan kualitas bangunan rumah yang memadai, namun masih memiliki kasus endemik Demam Berdarah Dengue (DBD) yang tinggi. Penelitian ini bertujuan untuk mengetahui karakteristik kejadian demam berdarah di tingkat rumah tangga.

Metode: Data dianalisis dari 781 rumah tangga yang terdiri dari 261 kasus dan 522 kontrol. Pemilihan sampel menggunakan metode kasus kontrol berpasangan dengan rasio 1:2. Tahapan penelitian terdiri dari pengamatan status rumah menggunakan form ceklis pemeriksaan dan wawancara menggunakan kuesioner tertutup. Analisis data korelasi pairwise spearmen, kemudian regresi logistik biner digunakan untuk prediksi faktor risiko.
\end{abstract}

Hasil: Faktor risiko usia produktif dan rendahnya tingkat pendidikan kepala keluarga, toilet yang kotor, dan status rumah tidak sehat memiliki pengaruh yang signifikan terhadap peningkatan kasus demam berdarah di Kota Bandung ((p<0.05). Faktor determinan adalah usia produktif kepala keluarga (31 - 60 tahun) dimana memiliki kemungkinan 2,53 (95\%CI 1.34-4.78;p<0.05) kali lebih besar untuk memiliki anggota rumah tangga yang menderita DBD di Bandung.

Kesimpulan: Usia dan pendidikan kepala rumah tangga, kebersihan toilet dan status rumah sehat memiliki peran penting dalam mempengaruhi kejadian demam berdarah. Dengan demikian, petugas kesehatan perlu melakukan promosi kesehatan mengenai DBD secara intensif kepada kepala rumah tangga. (Health Science Journal of Indonesia 2020;11(1):45-51)

Kata kunci: Demam Berdarah Dengue (DBD), kepala rumah tangga, usia, sanitasi rumah, Kota Bandung

\begin{abstract}
Background: Bandung have urban areas with adequate housebuilding quality, yet still has high Dengue endemic cases. This study aims to investigate the characteristics of dengue incidence at the household level.

Methods: Data analyzed from 781 households consisted of 261 cases and 522 controls. We applied matched case-control samples with a ratio of 1:2 (case: controls). The stages of the research consisted of a house status observation using a form inspection checklist and interviews using a closed-ended questionnaire. The data analyzed by pairwise spearmen correlation and binary logistic regression for risk factor prediction.
\end{abstract}

Results: Risk factors for productive age and low level of education of family heads, dirty toilets, and unhealthy house status have a significant effect on the increase of dengue cases in Bandung $(\mathrm{p}<0.05)$. The determinant factor is the productive age of the head of the family (31 - 60 years), it means that the family who has a family head in a productive age is $2.53(95 \%$ CI 1.34-4.78; $\mathrm{p}<0.05)$ times more likely to have a household member suffering from DHF in Bandung.

Conclusion: The age and the level of education of the household heads, toilet hygiene, and healthy home status have an essential role in influencing dengue fever. Therefore, health workers need to perform an intensive health promotion regarding DHF to the household heads. (Health Science Journal of Indonesia 2020;11(1):45-51)

Keywords: Dengue, head of household, ages, house sanitation, Bandung City 
Dengue haemorrhagic fever (DHF) is a mosquito-borne disease caused by Dengue virus and transmitted by Aedes aegypti and Ae. albopictus. Dengue infection has become a major public health problem worldwide, especially in Asia. In recent decades, the disease outbreak has been reported in 128 countries with more than 3.79 billion people are at risk, mostly in urban and semi-urban areas. ${ }^{1}$ In Southeast Asia, Dengue is endemic in 12 countries. An estimated 2.9 million dengue infections occur annually with 5,906 among them died, thus impacting the annual economic burden of US \$ 1.65 (the US \$ 1.06 - the US \$ 2.41) per capita. ${ }^{2}$

The government of Indonesia has conducted various efforts to prevent dengue transmission by physical, biology, chemical, empowering of community, and integrated management control, but dengue morbidity keeps increasing. Indonesia has reported that the morbidity rate of dengue still increases to 700 times in the last 45 years, whereas the mortality rate decreases to 56.16 times. ${ }^{3}$ dengue vector-density and human mobility cause rapid spread of dengue virus in Indonesia. We investigated the changes in dengue haemorrhagic fever (DHF However, Indonesia has not succeeded in preventing and controlling Ae. Aegypti from dengue virus transmission in both rural and urban settlements.

Household activities may play a role in the transmission of Dengue Fever. Various factors, such as house sanitation, room construction, occupants' behavior, management of water containers ${ }^{4}$ sanitation and hand hygiene in low- and middle-income settings and provide an overview of the impact on other diseases. $\mid$ nn $\backslash$ nMETHODS: For estimating the impact of water, sanitation and hygiene on diarrhea, we selected exposure levels with both sufficient global exposure data and a matching exposure-risk relationship. Global exposure data were estimated for the year 2012, and risk estimates were taken from the most recent systematic analyses. We estimated attributable deaths and disability-adjusted life years (DALYs, socio-economic conditions and knowledge about dengue fever have the potential to influence the incidence of dengue fever. Communities with less stable socio-economics condition tend to have inadequate or unhygienic houses. The previous study about risk factor analysis showed that residents in rented houses are more at risk of dengue than those who live in their own houses $(\mathrm{AOR}=2.2,95 \%$ $\mathrm{CI}=1.1-4.6 ; \mathrm{p}<0.05)$. In addition, residents of unhygienic dwellings were more likely to get dengue compared to residents in hygienic houses $(\mathrm{AOR}=$ $3.4,95 \% \mathrm{CI}=1.0-11.7 ; \mathrm{p}<0.05) .{ }^{5}$ The behavior of increasing house hygiene and vector control efforts were also closely related to the knowledge and attitudes of the community. Several studies have suggested that proper education and beliefs about dengue are related to the prevention of dengue. ${ }^{6-8}$ These determinant factors significantly affect the ongoing transmission of dengue in several regions.

The region with the highest risk of increasing DHF cases is the area in the center of Bandung, with peak cases from January to August. Many people are at risk of catching the dengue fever in the center of Bandung due to socio-economic conditions, especially slum housing conditions, population density, relatively high mobility, and low education levels. ${ }^{9}$ Respati's research (2018) states that the most decisive risk factors in the prevention and control of dengue in Bandung are community participation, housing, environmental factors, and climate. ${ }^{10}$

In Bandung, most of the citizens use containers for collecting and storing water for daily needs. These conditions will trigger an increase in the population of Aedes and the potential for the Dengue transmission. In 2010, at least of 3,430 Dengue cases were reported in this city. However, in the following two years (2013), the dengue cases were increased to 5,736 cases. ${ }^{11}$ The free larvae index was also increased and close to the national target at $93.38 \% .{ }^{12}$ In this study, we have investigated the characteristic of the dengue incidence at the household level in Bandung, Indonesia

\section{METHODS}

\section{Study Subjects}

Bandung is the capital of the West Java Province, located at coordinates of $107^{\circ} \mathrm{E}$ and $6^{\circ} 55^{\prime} \mathrm{S}$. Bandung has 75 PHCs (Primary Health Care/Pusat Kesehatan Masyarakat), as a unit in sub-district level that responsible for the community health efforts, consisting of public health activities for the population within their working area. This study has been carried out in 4 PHCs areas, i.e. Dago, Sekejati, Kopo, and Cipamokolan. The location of this study was determined based on the highest dengue case. This study also refers to research on Determining Risk Factors for Residential Sanitation in Dengue Hemorrhagic Fever (DHF) in Bandung in 2016. ${ }^{13}$ This study aims to explain what factors cause the number of healthy home coverage continues to show an increasing trend every year, despite the increasing trend of dengue fever as well. 
This research is observation research with a matched case-control design with a ratio of $1: 2$ so that the confounding factor in both groups can be controlled. The case group population is a house that has household members who have had DHF in 2015 in Bandung, while the control population is a house where household members have never had DHF in Bandung. The sample size was calculated using the odds ratio estimation formula, and a total sample of 783 households was obtained, consisting of 261 case groups and 522 control groups. The criteria for selecting a research location were if the puskesmas has a high number of dengue cases in 2015 in the city of Bandung. The sample selection of case group households uses a systematic random sampling technique, while the control group uses purposive sampling techniques with the criteria of a control group household being at a radius of 100 meters from the sample cases.

\section{Data Collection}

Data were collected through observation and interviews. The observation using the Ministry of Health's standard questionnaire viz healthy housing inspection checklist to determine the house status based on the regulation of the Ministry of Health, Republic of Indonesia No. 829/Menkes/VII/1999. There were four observed places, such as living/family room, bedroom, bathroom, and kitchen. This study evaluated all room construction (ceilings, walls, floors, windows, vents, chimney, and lighting), and sanitation facilities (water facilities, toilets, wastewater disposal, and garbage cans). After observation on four rooms, KAP interviews using structural questionnaire were conducted with some question to respondents about vector, transmission, and control of Dengue

\section{Data Analysis}

Status of a healthy house determined by calculating the weight of each component. The result of the calculation compared with the average standard value. The value for room construction is 44 , and the value for sanitation facilities is 31 . Based on the Arikunto criteria (2003), a $75 \%$ cut-off $^{14}$ can be used to determine the status of healthy and unhealthy houses. Then the house is characterized as a healthy house if the total amount achieved is $641-855$ and an unhealthy house if the total amount obtained is less than 641 . Then, the data analyzed by bivariate analysis using pairwise Spearman correlation. After that, multivariate analyses were performed to determine the dominant risk factor in affecting the incidence of Dengue in Bandung. Later, those variables were analyzed through binary logistic regression using Minitab version 19.

\section{Ethics Approval}

As this research involving humans as subjects, the research ethics approval was required. Therefore, research ethics approval letter has been published by the National Institute of Health Research and Development of Indonesia with Registration Number LB.02.01/5.2/KE.056/2016. The respondents gave a statement written in informed consent.

\section{RESULTS}

\section{Characteristics of Dengue Incidences}

The data samples of 783 respondents were successfully collected, which distributed to four Public Health Centers. As for the distribution consisted of 67 cases and 134 controls in Dago PHCs, 60 cases and 120 controls in Sekejati PHCs, 72 cases and 144 controls in Kopo PHCs, also 62 cases and 124 controls in Cipamokolan PHCs.

Result of the head of household characteristic component for case and control groups showed that the majority of households considered as a settled family with the indicator of age included into the productive period ( $95.02 \%$ and $88.70 \%$ ), level of education ranged from high school to higher education $(65.52 \%$ and $56.90 \%)$, and income $(70.11 \%$ and $65.33 \%$ ) was more than the regional minimum wage of Bandung $(2,310,000$ IDR), respectively. There are different age period and education level of head of household between case and control group $(p<0.05)$ (Table 1). Overall, the value of the house component consisting of the construction of houses, and sanitation facilities, both in case and control group was relatively similar. For a few different house components, namely the ventilation, and chimney, $(\mathrm{p}<0.05)($ Table 1).

House status showed that the majority of the Bandung citizen still included in the category of an unhealthy house, both in case and control group $(83.14 \%$ and $89.08 \%$ ). Moreover, the significantly different result was related to the house status to the incidence of Dengue in Bandung $(\mathrm{p}<0.05)$ (Table 2). The majority of Bandung citizen had inadequate knowledge (75.48\% and $72.99 \%$ ) regarding the transmission and eradication of Dengue, yet they had a right attitude $(93.87 \%$ and $91.76 \%)$, and action $(60.15 \%$ and $66.48 \%)$ concerning the prevention of Dengue. No significant different results related to knowledge, attitudes, and practices to the incidence of Dengue ( $>0.05)$ (Table 3 ). 
Table 1. Assosiation between house components with Dengue incidences

\begin{tabular}{lcc}
\hline \multirow{2}{*}{ No House Components } & \multicolumn{2}{c}{ Houses } \\
\cline { 2 - 3 } & $\begin{array}{c}\text { Case, } \\
\mathrm{n}=261\end{array}$ & $\begin{array}{c}\text { Control, } \\
\mathrm{n}=522\end{array}$ \\
\hline
\end{tabular}

1 Household head

Age of household head

Productive (16-60

Year)

Not Productive $(>60 \quad$ 13(4.98) $\quad 59(11.30)$

Year)

Education of household

head

$\geq$ Senior High School

$<$ Senior High School

Income of household

head

$\geq 3,000,000 \mathrm{IDR}$

$<3,000,000$ IDR

2 House constructions

Ceiling

Healthy

Unhealthy

Wall

Healthy

Unhealthy

Floor

Healthy

Unhealthy

Bedroom window

Healthy

Unhealthy

Living room window

Healthy

Unhealthy

Ventilation

Healthy

Unhealthy

Chimney

Healthy

Unhealthy

Sunlight

Healthy

Unhealthy

3 Sanitation facilities

Clean water

Healthy

Unhealthy

Toilet

Healthy

Unhealthy

Waste disposal

Healthy

Unhealthy

Garbage disposal

Healthy

\begin{tabular}{ccc} 
Unhealthy & $68(26.05)$ & $126(24.14)$ \\
\hline House components is Part of Physical building inside of house
\end{tabular} and householder behaviours, and was revealed of healthy when it's still functioning well and could prevent the disease's transmission;

* Candidates for Multivariate Analysis.

90(34.48) 225(43.10)

183(70.11) $341(65.33)$

$0.180^{*}$

78(29.89) $181(34.67)$

0.477

203(77.78) $394(75.48)$

$58(22.22) \quad 128(24.52)$

233(89.27) 460(88.12)

28(10.73) 62(11.88)

237(90.80) 477(91.38)

24(9.20) 45(8.62)

184(70.50) 367(70.31)

77(29.50) $155(29.69)$

230(88.12) 475(91.00)

31(11.88) $\quad 47(9.00)$

140(53.64) 319(61.11)

121(46.36) 203(38.89)

161(61.68) $369(70.69)$

$100(38.32) \quad 153(29.31)$

155(59.39) 275(52.68)

106(40.61) 247(47.32)

0.635

0.789

0.956

$0.206^{*}$

$0.045^{*}$

$0.011^{*}$

$0.076^{*}$

201(77.01) 399(76.44)

60(22.99) 123(23.56)

152(58.24) 327(62.64)

109(41.76) 195(37.36)

218(83.52) 437(83.72)

$43(16.48) \quad 85(16.28)$

0.559

193(73.95) 396(75.86)

0.858

$0.234^{*}$

0.946
Table 2. Association of house status with Dengue incidences

\begin{tabular}{lcccc}
\hline & & \multicolumn{2}{c}{ Houses } & \\
\cline { 3 - 4 } No & House Status & Case, & $\begin{array}{c}\text { Control, } \\
\mathrm{n}=522\end{array}$ & p-value \\
& & $\mathrm{n}=261$ & & \\
\hline 1 & Houses & & & \\
& Healthy & $44(16.86)$ & $57(10.92)$ & $0.019 *$ \\
& Unhealthy & $217(83.14)$ & $465(89.08)$ & \\
\hline
\end{tabular}

$>$ Houses status are revealed healthy when whole of the house components assessment has value more than 641.25 based on Decree of the Minister of Health of the Republic of Indonesia No.829/ Menkes/VII/1999 concerning the requirements of healthy housing

Table 3. Association of knowledges, attitudes, and practices with Dengue incidences

\begin{tabular}{|c|c|c|c|c|}
\hline \multirow[b]{2}{*}{ No } & \multirow[b]{2}{*}{ Variables } & \multicolumn{2}{|c|}{ Houses } & \multirow[b]{2}{*}{ p-value } \\
\hline & & $\begin{array}{c}\text { Case, } \\
\mathrm{n}=261\end{array}$ & $\begin{array}{c}\begin{array}{c}\text { Control, } \\
\mathrm{n}=522\end{array} \\
\end{array}$ & \\
\hline \multirow[t]{3}{*}{1} & Knowledge & & & 0.456 \\
\hline & Good & $64(24.52)$ & $141(27.01)$ & \\
\hline & Poor & $197(75.48)$ & $381(72.99)$ & \\
\hline \multirow[t]{3}{*}{2} & Attitudes & & & 0.293 \\
\hline & Positive & $245(93.87)$ & 479(91.76) & \\
\hline & Negative & $16(6.13)$ & $43(8.24)$ & \\
\hline \multirow[t]{3}{*}{3} & Practices & & & $0.082 *$ \\
\hline & Good & $157(60.15)$ & $347(66.48)$ & \\
\hline & Poor & $104(39.85)$ & $175(33.52)$ & \\
\hline
\end{tabular}

\section{Determinants of Dengue}

The goodness of fit on logistic regression analysis showed that p-value of Hosmer Lemeshow was 0.499 , indicated that the model is fit to be postulated. The value of concordant is 65.1 , which means that probably there is only $65.1 \%$ risk factor variable correlated with the incidence of Dengue in Bandung. Risk factors that influence the increase in DHF are the age and the education of the household head, toilet, and the status of the healthy house $(\mathrm{p}<0.05)$. As for the most dominant risk factor of the spread of Dengue in Bandung is the age of household head which is still productive which leads to a tendency of dengue infection risk with OR 2.53 (95\% CI, 1.344.78).

\section{DISCUSSIONS}

In this study, the majority of cases of dengue infection in Bandung in 2016 lived in urban areas with good socioeconomic status, but they lived in houses with poor sanitation and lack of practice and behavior in vector control. This study also revealed that dirty toilets, bathtubs that are rarely drained, frequent use of insecticides, and lack of vector control efforts will 
increase the risk of family members infected with dengue fever / DHF. In Kediri-Indonesia it was found that the activity to prevent Dengue through mosquito breeding sites eradication in the form of water container management has a significant correlation with the increase in Dengue cases. ${ }^{15}$ Previous studies also reported that the condition of toilets in parts of Kuala Lumpur ${ }^{16}$ and Thailand ${ }^{17}$ related to the existence of Aedes spp; as well as in Venezuela. It stated that the practice of vector prevention was negatively associated with dengue cases. ${ }^{18}$

The attitudes and actions of the people of Bandung City have shown functional categories in efforts to control the vector of DHF, but it is not supported by good knowledge as well. The impact is the community makes efforts to clean the house environment as daily tasks, but the city has not made an effort to eradicate mosquitoes routinely and precisely. Some people of the City of Bandung admit that attempts to drain water are often but not routine and not accompanied by brushing actions, so the possibility of mosquito eggs attached to the walls of water containers can grow into adult mosquitoes. Therefore, comprehensive knowledge about Dengue should also be taken into consideration since inadequate knowledge will not have an impact on the behaviors of mosquito breeding sites eradication in total. ${ }^{19-21}$

The existence of water containers in the toilet can become a potential habitat for Aedes aegypti breeding such as bathtubs and buckets. ${ }^{22,23}$ Stagnant water in containers that are not drained and brushed for more than nine days can be a habitat that is loved by Aedes aegypti to complete the life cycle of mosquitoes ranging from eggs, larvae, pupae, to adults. ${ }^{24}$ Aedes aegypti adults infected with dengue virus can become dengue vectors during their lifetime between 15-65 days ${ }^{25}$; as long as its blood needs are met, Aedes aegypti will always be active inside the house. Therefore, in dengue-endemic areas, it was reported that household members who live at house with dengue patient have the opportunity to become infected with dengue 3.2 times (95\% CI 1.8-5.7) ${ }^{26}$

The results of the binary logistic regression analysis showed that the productive age of the head of the household had a dominant role in dengue transmission in the city of Bandung (Table 4). This finding explains that the activity of the head of the household outside the home all day has caused the lack of time and ability to coordinate other family members to carry out DHF control efforts.
Table 4. Binary Logistic Regression Analysis on determinants of dengue incidence characteristics

\begin{tabular}{clcc}
\hline No & \multicolumn{1}{c}{ Variables } & Odds Ratio 95\% CI, & p-value \\
\hline 1 & Age of household head & $2.53(1.34-4.78)$ & $0.004^{* *}$ \\
2 & Education of & $1.39(1.00-1.93)$ & $0.048^{*}$ \\
& household head & & \\
3 & Living room window & $0.65(0.39-1.77)$ & 0.095 \\
4 & Chimney & $0.73(0.52-1.03)$ & 0.078 \\
5 & Toilet & $0.68(0.48-0.96)$ & $0.027^{*}$ \\
6 & Practices & $0.73(0.53-1.00)$ & 0.055 \\
7 & Healthy house & $1.72(1,05-2.83)$ & $0.031^{*}$ \\
\hline
\end{tabular}

Important information in this study is that the majority of DHF patients and their household heads are in the phase where they are productive. They occupy a sturdy house but pay less attention to aspects of vector control of DHF. This phenomenon is probably due to the lack of complete community knowledge about DHF. This phenomenon can result in the spread of DHF from the workplace to the residential environment, and transmit DHF to household members who live at home, to reduce family productivity. The mean number of workdays lost for adult DHF patients was 7.6 (SD 3.1) days; ${ }^{27}$ as well as the head of the family who must treat patients while in hospital. Therefore, serious efforts are needed from the Bandung local government to provide systematic education on the control of DHF vectors at the household level to the head of the household, so that they are motivated to make efforts to eradicate mosquito nests regularly and appropriately. The hope is that the head of the house can invite all members of his family to start a clean and healthy life, especially in preventing dengue transmission.

The limitation of this study was that this study did not do in-depth interviews related to the explanation of why the people of Bandung City were low in knowledge but had good vector control attitudes and actions, though the means to access media information about DHF is very easy to obtain. Besides, no more digging about the mobility of household heads in maintaining the socioeconomic status of the community in the city of Bandung.

In conclusion, the description above explains that the incidence of Dengue caused by are the age and the education of the household head, toilet condition, and the status of healthy house. Therefore, it is necessary to establish cadres to promote the information about Dengue to the household heads. And also, the cadres must inspect and clean houses where larvae of Aedes spp. are found. 


\section{Acknowledgments}

We would like to thanks to the National Institute of Health Research and Development of the Ministry of Health, Indonesia for funding this research, and also Health Department of Bandung for providing facilities to researchers thus this research can be well completed. This research is fully supported by the Pangandaran Unit of Vector-borne Diseases Control. Therefore, no conflicts of interest in this original research.

\section{REFERENCES}

1 Brady OJ, Gething PW, Bhatt S, Messina JP, Brownstein JS, Hoen AG, et al. Refining the global spatial limits of Dengue Virus transmission by evidence-based consensus. PLoS Negl Trop Dis. 2012; 6. doi:10.1371/ journal.pntd.0001760.

2 Shepard DS, Undurraga EA, Halasa YA. Economic and disease burden of Dengue in Southeast Asia. PLoS Negl Trop Dis. 2013; 7: e2055.

3 Karyanti MR, Uiterwaal CSPM, Kusriastuti R, Hadinegoro SR, Rovers MM, Heesterbeek H, et al. The changing incidence of Dengue Haemorrhagic Fever in Indonesia: a 45-year registry-based analysis. BMC Infect Dis. 2014; 14. doi:10.1186/1471-2334-14-412.

4 Prüss-Ustün A, Bartram J, Clasen T, Colford JM, Cumming O, Curtis V, et al. Burden of disease from inadequate water, sanitation and hygiene in low- and middle-income settings: a retrospective analysis of data from 145 countries. Trop Med Int Heal. 2014; 19: 894 905.

5 Toan DTT, Hoat LN, Hu W, Wright P, Martens P. Risk factors associated with an outbreak of dengue fever/dengue haemorrhagic fever in Hanoi, Vietnam. Epidemiol Infect. 2015; 143: 1594-8.

6 Harapan H, Bustamam A, Radiansyah A, Angraini P, Fasli R, Salwiyadi S, et al. Dengue prevention: confirmatory factor analysis of relationships between economic status, knowledge, attitudes and practice, vaccine acceptance and willingness to participate in a study. Southeast Asian J Trop Med Public Health. 2017; 48: 297-305.

7 Rao, Minhat, Hayati. Predictors of practices related to dengue fever prevention among international students in Universiti Putra Malaysia, Serdang. Int J Public Heal Clin Sci. 2016; 3: 36- 47.

8 Fuadzy H, Widawati M, Hodijah DN, Wahono T. The Role of Information Channels to Encourage Mosquito Breeding Site Eradication for Community of Bandung City. Bul Penelit Sist Kesehat. 2019; 22: 27-33.

9 Jaya IGNM, Folmer H. Bayesian spatiotemporal mapping of relative dengue disease risk in Bandung, Indonesia. J Geogr Syst. 2020;22:105-142.

10 Respati T, Feriandi Y, Ndoen E, Djuhaeni H, Sofyan A, Dale D. A qualitative eco-health model of Dengue Fever (DF) in Bandung, Indonesia. Int J Trop Dis. 2018;1.
11 West Java Provincial Health Office. Report on Dengue Hemorrhagic Fever Case 2009-2013. [Unpublished]. Bandung; 2014.

12 Bandung Health Office. Bandung City Health Profile 2011. (Unpublished). Bandung; 2011.

13 Fuadzy H, Astuti EP, Prasetyowati H, Hendri J, Rohmansyah, Hodijah DN. Determining risk factors for residential sanitation in Dengue Hemorrhagic Fever (DHF) in Bandung in 2016. Final Report. Pangandaran Unit of Health Research and Development, Ministry of Health of Indonesia. Pangandaran, 2016.

14 Arikunto S. Prosedur penelitian suatu pendekatan praktik. Rineka Cipta:Jakarta;2010. Indonesian.

15 Hakim L, Yanuwiadi B, Hariyono, Suyadi, Hakim L, Yanuwiadi B. The role of environmental and behavior factors to dengue fever incidents. J Appl Environ Biol Sci. 2016;6:1-8.

16 Mahmud MAF, Mutalip MH, Lodz NA, Shahar H. Study on key Aedes spp breeding containers in dengue outbreak localities in Cheras district, Kuala Lumpur. Int J Mosq Res. 2018;5:23-30.

17 Waewwab P, Sungvornyothin S, Okanurak K, Soonthornworasiri N, Potiwat R. Characteristics of water containers influencing the presence of Aedes immatures in an ecotourism area of Bang Kachao Riverbend, Thailand. J Heal Res. 2019;33:398-407.

18 Elsinga J, Schmidt M, Lizarazo EF, Vincenti-gonzalez MF, Velasco-salas ZI, Arias L, et al. Knowledge, attitudes, and preventive practices regarding Dengue in Maracay, Venezuela. Am J Trop Med Hyg. 2018;99:195-203.

19 Jeelani S, Sabesan S, Subramanian S. Community knowledge, awareness and preventive practices regarding dengue fever in Puducherry - South India. Public Health. 2015;129:790-6.

20 Elyas TB, Elsidig EM, Aseri A, Break A, Salim H, Adil $\mathrm{R}$, et al. Knowledge, attitudes and preventive practices of household regarding Dengue Fever in the rural areas of Jazan Region, Saudi Arabia. Int J Prev Med Res. 2016;2:8-12.

21 Alobuia WM, Missikpode C, Aung M, Jolly PE. Knowledge, attitude, and practices regarding vectorborne diseases in Western Jamaica. Ann Glob Heal. 2015;81:654-63.

22 Prasetyowati H, Ipa M, Widawati M. Pre-adult survey to identify the key container habitat of Aedes Aegypti (L.) in Dengue Endemic areas of Banten Province, Indonesia. Southeast Asian J Trop Med Public Health. 2018;49:23-31.

23 Wijayanti SPM, Octaviana D, Nurlaela S. Mosquito indices in outdoor spatial spraying treated area, Banyumas Regency, Indonesia. IOP Conf Ser Earth Environ Sci. 2019;255:0120033.

24 Collett GC, Graham JE, Schoof HF, Quarterman $\mathrm{KD}$, Johnson DR, Barnes AM, et al. Vector Control in International Health. World Health Organization:Switzerland; 1972. 
25 Chakraborty T, Alcamo IE. Dengue fever and other hemorrhagic viruses (deadly diseases \& epidemics). New York: Infobase Publishing. 2008.

26 Chien Y, Huang H, Ho T, Tseng F, Ko N, Ko W, et al. Seroepidemiology of dengue virus infection among adults during the ending phase of a severe dengue epidemic in southern Taiwan, 2015. BMC Infec. 2019;19:1-9.

27 Tozan Y, Ratanawong P, Sewe MO, Wilder- A, Kittayapong P. Household costs of hospitalized dengue illness in semi-rural Thailand. PLoS Negl Trop Dis. 2017; 11: e0005961. 